\author{
Katarzyna Pieklarz, Alicja Zawadzka \\ Technical University of Lodz, Faculty of Process and Environmental Engineering \\ 213 Wolczanska Str., 90-924 Lodz, Poland, katarzyna.pieklarz@dokt.p.lodz.pl, alicja.zawadzka@p.lodz.pl
}

\title{
THE USE OF BIOFILTRATION PROCESS TO REMOVE MALODOROUS GASES FROM THE WASTEWATER TREATMENT PLANT
}

\begin{abstract}
Odorous substances emitted to ambient air from wastewater treatment plants cause a serious nuisance to inhabitants in the direct vicinity of such emitters. The solutions currently used to remove malodorous gases in the Wastewater Treatment Plant in Belchatow do not fulfill their function properly. This article presents the test results of the composition and concentrations of odorous compounds emitted from the abovementioned plant. In addition, the paper introduces the concept of eliminating substances by the biofiltration process. Due to the applied method, one can expect to reduce the odor by at least $90 \%$.
\end{abstract}

\section{Key words}

Biofiltration process, biofilter, microorganisms, malodorous gases, wastewater treatment plant

\section{Introduction}

Over the past few decades, enormous quantities of pollutants have been released into the environment, mainly into the air. Due to high emission of a wide variety of pollutants, there has been an increase in the number of environment-related problems. These compounds are usually removed slowly and tend to accumulate in the environment. Because of the high degree of toxicity, their accumulation can cause severe environmental problems. Therefore, scientists are conducting research to introduce new methods for removing odorous substances emitted mainly from wastewater treatment plants $[4,5,8,9]$.

Particularly promising solutions include biological methods, especially the biofiltration process. It is a complex biological process of removing malodorous substances consisting in the biodegradation of pollutants, whose products are non-toxic compounds inert to the environment. Both physical and biological processes occur during biofiltration [15].

Odorous contaminants occurring in the exhaust gases are subjected to the process of adsorption on the surface of the liquid bioactive layer (Figure 1.) that surrounds the grain fill - the filter material $[1,14,15]$.

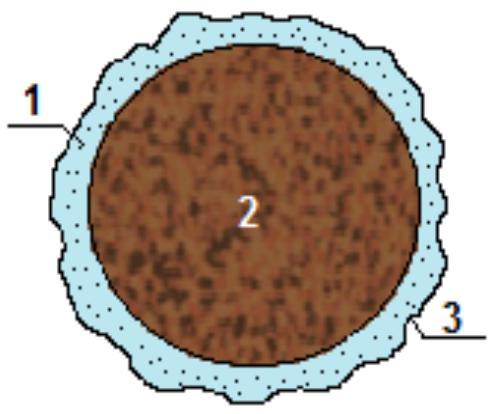

Fig. 1. Schematic of a biofilm covering the filter material 1 - microorganisms, 2 - filter material, 3 - bioactive layer Source: Author's

The particles of odor adsorbed on the surface of the biofilm pass into the liquid phase and then diffuse into microorganisms colonizing the bioactive layer. In this layer, the microorganisms bring about the biodegradation of odorous pollutants to carbon dioxide, water and other organic compounds (biomass). The biomass causes the growth of microorganisms capable of increased distribution of impurities in mineralization involving 
mainly bacteria of the genus: Pseudomonas, Micrococcus, Corynebacterium, Hyphomicrobium, Rhodococcus, Xanthobacter, Arthrobacter, Methylomonas or Thiobacillus and fungi $[2,6,10,11]$.

The biofiltration process is conducted in a biofilter, which comprises a housing and a layer of filling of the porous filter material. The material is inhabited by microorganisms capable of biological decomposition of the pollutant gas. The shape of biological filters depends mainly on the spatial potential and the scale of their use. Therefore, there are different types of biofilters in terms of construction, and types of fillers or additives and treatments that enhance the effectiveness of gas purification. In the case of laboratory testing, biofilters are very simple devices - usually pipes with a length of several tens of centimeters. Currently, both open and closed surface and container biofilters are used on a technical scale worldwide, and their height ranges from several tens of centimeters to several meters $[3,15,16]$.

The diagram below (Figure 2) illustrates the treatment process of waste gases by biofiltration.

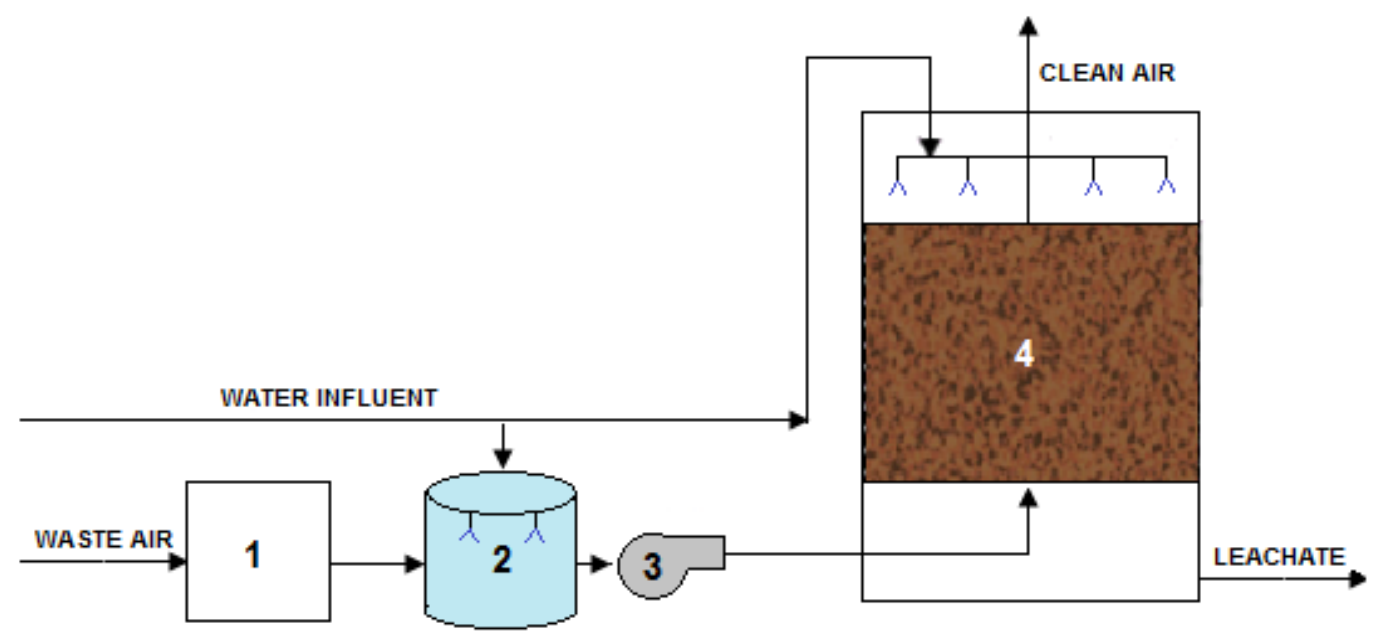

Fig. 2. Schematic diagram of a biofilter unit

1 - preconditioner for particulate removal, 2 - humidifier, 3 - blower, 4 - biofilter reactor Source: Author's

As the schematic shows, the contaminated off-gas is passed through a preconditioner for particulate removal and humidification. The conditioned gas stream is then passed from the bottom of a filter bed with, for example, soil, peat, composted organic material or activated carbon. These media provide a surface for the attachment and growth of microorganisms. The bed and air stream are kept moist to encourage microbial activity. Humidification is the most influential parameter affecting the sorptive capacity $[5,12,13]$.

The aim of this research was to perform analyzes of the composition and concentrations of malodorous substances (organic and inorganic ones) emitted from the Wastewater Treatment Plant in Belchatow.

\section{Material and methods}

To carry out the measurements, five representative research points located in the mechanical and biological facilities of the Wastewater Treatment Plant in Belchatow were selected (the primary settling tank, outdoor pool fermentation No. 1, outdoor pool fermentation No. 2, the phosphorus removal chamber and the nitrification chamber).

Samples for analytical testing were taken with the low flow suction pump equipped with a flow meter and a flow controller made by SENSIDYNE Co.

The identification and measurement of the concentration of inorganic compounds such as carbon monoxide, hydrogen sulfide, aliphatic hydrocarbons and ammonia were performed with the exhaust gas analyzer "LANCOM Series II" made by LAND Instruments Co. 
The analysis of organic impurities was performed by gas chromatography with a mass detector made by VARIAN Co. after desorption from activated carbon. Before the analysis, the compounds were concentrated in short columns filled with activated carbon. Coal, before being placed in columns, was washed of $1.0 \mathrm{M} \mathrm{HCl}$ and heated to the boiling point to remove the compounds adsorbed on its surface. Thus, prepared activated carbon was placed in columns ( $100 \mathrm{~mm}$ in length and $5 \mathrm{~mm}$ in diameter each), in two portions. The first layer had a weight of $200 \mathrm{mg}$, and the second weighed $100 \mathrm{mg}$. Then, within 30 minutes, the test air was passed through the columns at a rate of $40 \mathrm{~L} \cdot \mathrm{h}^{-1}$. The next step of the study involved an independent extraction of layers of activated carbon with used carbon disulphide, and the chromatographic analysis of obtained extracts.

The acquired chromatographic image detected about 36 - 42 compounds (depending on the sample) which could not be identified. The surface area of the peaks of unidentified compounds was converted to the field of pentane, and was recognized as the sum of aliphatic hydrocarbons $\left(\Sigma \mathrm{C}_{\mathrm{x}} \mathrm{H}_{\mathrm{y}}\right)$.

\section{Results and discussion}

The test results are presented in Table 1 and compared with the permissible concentrations of pollutants in the air specified in the Regulation of the Minister of the Environment of 26 January 2010 on reference values for certain substances in the air [7].

Table 1. The results of air samples analyze

\begin{tabular}{|c|c|c|c|c|c|c|c|}
\hline $\begin{array}{l}\text { Component } \\
\text { of the air }\end{array}$ & Unit & $\begin{array}{l}\text { Results for } \\
\text { primary } \\
\text { settling tank }\end{array}$ & $\begin{array}{c}\text { Results for } \\
\text { outdoor pool } \\
\text { fermentation } \\
\text { No. } 1\end{array}$ & $\begin{array}{c}\text { Results for } \\
\text { outdoor pool } \\
\text { fermentation } \\
\text { No. } 2\end{array}$ & $\begin{array}{c}\text { Results for } \\
\text { phosphorus } \\
\text { removal } \\
\text { chamber }\end{array}$ & $\begin{array}{c}\text { Results for } \\
\text { nitrification } \\
\text { chamber }\end{array}$ & Permissible value \\
\hline $\mathrm{SO}_{2}$ & $\mathrm{mg} \cdot \mathrm{m}^{-3}$ & 63.0 & 11.0 & 69.0 & 1.6 & 1.2 & 0.35 \\
\hline $\mathrm{CO}$ & $\mathrm{mg} \cdot \mathrm{m}^{-3}$ & 24.0 & 40.0 & 18.0 & 3.6 & 3.9 & 30.0 \\
\hline $\mathrm{H}_{2} \mathrm{~S}$ & $\mu g \cdot m^{-3}$ & 126.0 & 100.0 & 151.0 & 28.0 & 19.0 & 20.0 \\
\hline$\Sigma \mathrm{C}_{\mathrm{x}} \mathrm{H}_{\mathrm{y}}$ & $\mathrm{mg} \cdot \mathrm{m}^{-3}$ & 1043.0 & 768.0 & 1289.0 & 202.0 & 198.0 & 3.0 \\
\hline$\Sigma$ mercaptans & $\mu g \cdot m^{-3}$ & 81.0 & 70.5 & 97.0 & 18.0 & 23.1 & 20.0 \\
\hline Dimethylamine & $\mu g \cdot m^{-3}$ & 105.0 & 84.0 & 116.0 & 20.0 & 15.0 & 10.0 \\
\hline Trimethylamine & $\mu g \cdot m^{-3}$ & 163.0 & 110.5 & 179.0 & 28.0 & 36.0 & 20.0 \\
\hline Ammonia & $\mu g \cdot m^{-3}$ & 126.0 & 100.0 & 141.0 & 39.0 & 47.0 & 400.0 \\
\hline Isobutyric acid & $\mu g \cdot m^{-3}$ & 87.0 & 81.0 & 96.0 & 28.0 & 14.0 & - \\
\hline Formaldehyde & $\mu g \cdot m^{-3}$ & 691.0 & 412.0 & 738.0 & 147.0 & 129.0 & 50.0 \\
\hline Skatole & $\mathrm{mg} \cdot \mathrm{m}^{-3}$ & 1.6 & 1.2 & 1.7 & $<1.0$ & $<1.0$ & - \\
\hline
\end{tabular}

Source: Author's

Completed analytical research shows that polymer gel mats and foggers used in the Wastewater Treatment Plant in Belchatow do not produce the expected results.

Several odorous compounds, including $\mathrm{SO}_{2}, \mathrm{CO}, \mathrm{H}_{2} \mathrm{~S}, \mathrm{NH}_{3}$, mercaptans, di- and trimethylamine, formaldehyde and other unidentified compounds presented as $\Sigma \mathrm{C}_{x} \mathrm{H}_{y}$, have been detected in the studied air samples. The concentration of the identified compounds has been exceeded several times, and sometimes hundreds of times the permissible concentrations of pollutants in the air. The air over the analyzed object also contains isobutyric acid and skatole, for which the Regulation of the Minister of the Environment of 26 January 2010 on reference values for certain substances in the air does not provide concentration limits, and the presence of which greatly affects the odor nuisance around the plant. 
Due to the continuously high level of substances emitted into the atmosphere from the Wastewater Treatment Plant in Belchatow, this plant is a threat to the environment. The undesirable substances emitted into the atmosphere pollute the air not only in the plant itself, but also in the surrounding neighborhoods, which lowers the quality of life of residents of nearby settlements. For this reason, it is necessary to arrange air treatment, modernize the facility and expand the treatment system.

\section{Concept of elimination of odorous substances}

The preferred method proposed here is to enter the air purification system using the biological method of biofiltration. This requires additional encapsulation of the wastewater treatment plant (sealing processes) with laminate covered roofs. The encapsulation process will focus on the following wastewater treatment plant facilities:

- primary settling tank,

- outdoor pool fermentation No. 1,

- outdoor pool fermentation No. 2,

- three technological strings of the biological part (each consisting of: one phosphorus removal chamber, two denitrification chambers and two nitrification chambers).

The size of the installation for deodorizing the air has been determined based on the balance of air for each biofilter, as shown in Table 2 (assuming the height of the roof in the central point of each of the facilities equals to $0.5 \mathrm{~m}$ and the air change rate of 5 exchanges $\cdot \mathrm{h}^{-1}$ ).

Table 2. The balance of air for each biofilter

\begin{tabular}{|c|c|c|c|}
\hline Name of the facility & $\begin{array}{c}\text { Volume } \\
{\left[\mathrm{m}^{3}\right]}\end{array}$ & $\begin{array}{c}\text { Multiplicity of air } \\
\text { exchange } \\
\left.\text { [exchanges } \cdot \mathbf{h}^{-1}\right]\end{array}$ & $\begin{array}{c}\text { Stream air } \\
\text { ventilation } \\
{\left[\mathrm{m}^{3} \cdot \mathrm{h}^{-1}\right]}\end{array}$ \\
\hline Primary settling tank & 471.24 & 5 & 2356.2 \\
\hline $\begin{array}{c}\text { Outdoor pool } \\
\text { fermentation No. 1 }\end{array}$ & 2094.4 & 5 & 10472.0 \\
\hline $\begin{array}{c}\text { Outdoor pool } \\
\text { fermentation No. 2 }\end{array}$ & 2094.4 & 5 & 10472.0 \\
\hline \multicolumn{2}{|c|}{ Total - balance for the biofilter 1 } & $\mathbf{2 3 3 0 0 . 2}$ \\
\hline \multicolumn{2}{|c|}{ One technological sequence of biological part } \\
\hline $\begin{array}{c}\text { Phosphorus removal } \\
\text { chamber }\end{array}$ & 72.0 & 5 & 360.0 \\
\hline $\begin{array}{c}\text { Denitrification } \\
\text { chamber No. 1 }\end{array}$ & 150.0 & 5 & 750.0 \\
\hline $\begin{array}{c}\text { Denitrification } \\
\text { chamber No. 2 }\end{array}$ & 615.0 & 5 & 3075.0 \\
\hline $\begin{array}{c}\text { Nitrification } \\
\text { chamber No. 1 }\end{array}$ & 288.0 & 5 & 1440.0 \\
\hline $\begin{array}{c}\text { Nitrification } \\
\text { chamber No. 2 }\end{array}$ & 288.0 & 5 & 1440.0 \\
\hline \multicolumn{2}{|c|}{ Total - balance for one technological sequence } & 7065.0 \\
\hline \multicolumn{2}{|c|}{ Balance for three technological sequences - biofilter 2 } & $\mathbf{2 1 1 9 5 . 0}$ \\
\hline
\end{tabular}

Source: Author's

The results of the calculations compiled in Table 2 indicate that the minimum capacity of biofilter No. 1 is $23300.2 \mathrm{~m}^{3} \cdot \mathrm{h}^{-1}$, and biofilter No. 2 is $21195.0 \mathrm{~m}^{3} \cdot \mathrm{h}^{-1}$.

The "BIO" type biofilters made by Laminopol Co. were proposed for purifying the exhaust air from the Wastewater Treatment Plant in Belchatow. Device No. 1 is a BIO24000 biofilter with a capacity of $24.000 \mathrm{~m}^{3} \cdot \mathrm{h}^{-1}$, which will handle the primary settling tank and outdoor pools fermentation. Device No. 2 is a BIO22000 biofilter with a capacity of $22.000 \mathrm{~m}^{3} \cdot \mathrm{h}^{-1}$, which is used to purify the air from the chambers of the biological part. The proposed biofilters are expected to use a filling made of coconut fibers with a porosity of $95 \%$ and a filter bed of $1.0 \mathrm{~m}$ in height. 
The biofilters of the "BIO" type are modular units consisting of a biomass tank made of polyester-glass laminate, which is resistant to the condensate of contaminated air, and a machine compartment equipped with an air humidifier and a blower. The material used to build the above mentioned biological filters ensures long-term operation of the equipment without maintenance work [19].

The location of biofilters in the wastewater treatment plant is shown in Figure 3. Biofilter No. 1 is proposed to be located about 30.0 m east of the primary settling tank, while biofilter No. 2 is proposed to be located about $15.0 \mathrm{~m}$ south of the denitrification chambers.

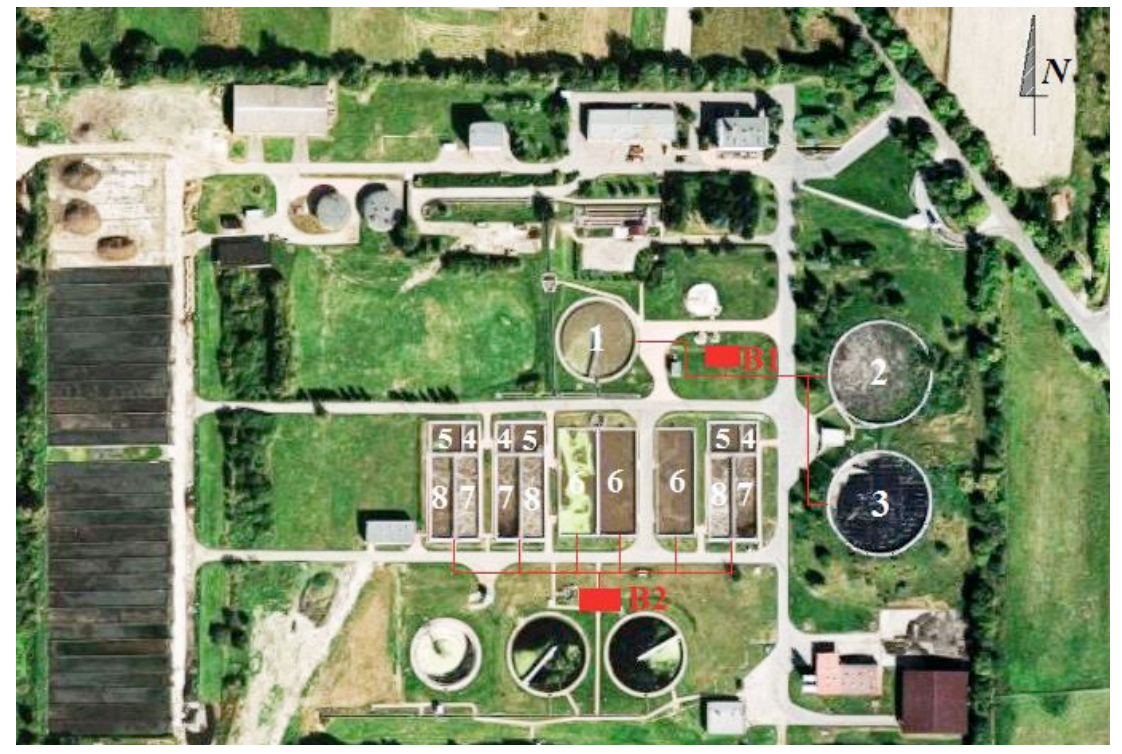

Fig. 3. The facilities of the Wastewater Treatment Plant in Belchatow have been encapsulated and proposed location of biofilters [18]:

1 - primary settling tank, 2 - outdoor pool fermentation No. 1, 3 - outdoor pool fermentation No. 2, 4 - phosphorus removal chamber, 5 - denitrification chamber No. 1, 6 - denitrification chamber No. 2, 7 - nitrification chamber No. 1, 8 - nitrification chamber No. 2, B1 - biofilter No. 1, B2 - biofilter No. 2

\section{Source: Author's}

\section{Expected effects of the biofiltration system}

It has been assumed that the installation of biofilters after commissioning will have the following air cleaning effects:

- the effectiveness of the reduction of odors will be ensured at the level of at least $95 \%$ with respect to $\mathrm{H}_{2} \mathrm{~S}$ and $\Sigma$ mercaptans,

- the effectiveness of the reduction of the remaining odor compounds will reach the level of at least $90 \%$ [17].

The results of the calculations of odorous substances obtained after the biofiltration process are summarized in Tables 3 and 4, and the example of the calculations for sulfur dioxide (biofilter No. 1) is shown by the following equations.

- Calculation of $\mathrm{SO}_{2}$ concentration before the biofilter

$$
c_{\mathrm{SO}_{2}}=\frac{c_{S_{2}(P S T)} \cdot V_{(P S T)}+c_{S_{2}(O P F 1)} \cdot V_{(O P F 1)}+c_{S_{2}(O P F 2)} \cdot V_{(O P F 2)}}{\sum V_{(\text {BIOFILTER } 1)}}\left[\mathrm{mg} \cdot \mathrm{m}^{-3}\right]
$$

where: $c_{\mathrm{SO}_{2}(P S T)}-\mathrm{SO}_{2}$ concentration in the air above the primary settling tank,

$$
c_{\mathrm{SO}_{2}(P S T)}=63.0 \mathrm{mg} \cdot \mathrm{m}^{-3},
$$

$V_{(P S T)}$ - ventilation air stream above the primary settling tank, 


$$
V_{(P S T)}=2356.2 \mathrm{~m}^{3} \cdot \mathrm{h}^{-1}
$$

$c_{\mathrm{SO}_{2}(\mathrm{OPF} 1)}-\mathrm{SO}_{2}$ concentration in the air above the outdoor pool fermentation No. 1,

$$
c_{\mathrm{SO}_{2}(\mathrm{OPF} 1)}=11.0 \mathrm{mg} \cdot \mathrm{m}^{-3}
$$

$V_{(O P F 1)}$ - ventilation air stream above the outdoor pool fermentation No. 1,

$$
V_{(O P F 1)}=10472.0 \mathrm{~m}^{3} \cdot \mathrm{h}^{-1}
$$

$c_{\mathrm{SO}_{2}(O P F 2)}-\mathrm{SO}_{2}$ concentration in the air above the outdoor pool fermentation No. 2,

$$
c_{\mathrm{SO}_{2}(\mathrm{OPF} 2)}=69.0 \mathrm{mg} \cdot \mathrm{m}^{-3}
$$

$V_{(O P F 2)}$ - ventilation air stream above the outdoor pool fermentation No. 2,

$$
V_{(O P F 2)}=10472.0 \mathrm{~m}^{3} \cdot \mathrm{h}^{-1}
$$

$\sum V_{(B I O F I L T E R 1)}$ - total air flow before the biofilter No. 1,

$$
\begin{gathered}
\sum V_{(\text {BIOFILTER } 1)}=23300.2 \mathrm{~m}^{3} \cdot \mathrm{h}^{-1} . \\
c_{\mathrm{SO}_{2}}=\frac{63.0 \cdot 2356.2+11.0 \cdot 10472.0+69.0 \cdot 10472.0}{23300.2}=\mathbf{4 2 . 3 3}\left[\mathrm{mg} \cdot \mathrm{m}^{-3}\right]
\end{gathered}
$$

- Calculation of $\mathrm{SO}_{2}$ concentration behind the biofilter, with assumed reduction rate $=90 \%$

$$
\begin{aligned}
& c_{S_{S_{2}}}^{\prime}=c_{\mathrm{SO}_{2}}-0.9 \cdot c_{\mathrm{SO}_{2}}\left[\mathrm{mg} \cdot \mathrm{m}^{-3}\right] \\
& c_{\mathrm{SO}_{2}}^{\prime}=42.33-0.9 \cdot 42.33=4.23\left[\mathrm{mg} \cdot \mathrm{m}^{-3}\right]
\end{aligned}
$$

Table 3. Concentration values of odorous substances obtained after air purification in biofilter No. 1

\begin{tabular}{|c|c|c|c|c|c|}
\hline $\begin{array}{c}\text { Component } \\
\text { of the air }\end{array}$ & Unit & $\begin{array}{c}\text { Concentration } \\
\text { before } \\
\text { the biofilter }\end{array}$ & $\begin{array}{c}\text { Degree of } \\
\text { pollutions } \\
\text { reduction [\%] }\end{array}$ & $\begin{array}{c}\text { Concentration } \\
\text { behind } \\
\text { the biofilter }\end{array}$ & Permissible value \\
\hline $\mathrm{SO}_{2}$ & $\mathrm{mg} \cdot \mathrm{m}^{-3}$ & 42.33 & 90.0 & 4.23 & 0.35 \\
\hline $\mathrm{CO}$ & $\mathrm{mg} \cdot \mathrm{m}^{-3}$ & 28.49 & 90.0 & 2.85 & 30.0 \\
\hline $\mathrm{H}_{2} \mathrm{~S}$ & $\mu \mathrm{g} \cdot \mathrm{m}^{-3}$ & 125.55 & 95.0 & 6.28 & 20.0 \\
\hline$\Sigma \mathrm{C}_{\mathrm{x}} \mathrm{H}_{\mathrm{y}}$ & $\mathrm{mg} \cdot \mathrm{m}^{-3}$ & 1029.97 & 90.0 & $\mathbf{1 0 3 . 0}$ & 3.0 \\
\hline$\Sigma$ mercaptans & $\mu \mathrm{g} \cdot \mathrm{m}^{-3}$ & 83.47 & 95.0 & 4.17 & 20.0 \\
\hline Dimethylamine & $\mu \mathrm{g} \cdot \mathrm{m}^{-3}$ & 100.51 & 90.0 & 10.05 & 10.0 \\
\hline Trimethylamine & $\mu \mathrm{g} \cdot \mathrm{m}^{-3}$ & 146.6 & 90.0 & 14.66 & 20.0 \\
\hline Ammonia & $\mu \mathrm{g} \cdot \mathrm{m}^{-3}$ & 121.06 & 90.0 & 12.11 & 400.0 \\
\hline Isobutyric acid & $\mu \mathrm{g} \cdot \mathrm{m}^{-3}$ & 88.35 & 90.0 & 8.84 & - \\
\hline Formaldehyde & $\mu \mathrm{gg} \cdot \mathrm{m}^{-3}$ & 586.73 & 90.0 & $\mathbf{5 8 . 6 7}$ & 50.0 \\
\hline Skatole & $\mathrm{mg} \cdot \mathrm{m}^{-3}$ & 1.44 & 90.0 & 0.14 & - \\
\hline
\end{tabular}

Source: Author's 
Moreover, it has been assumed that:

- the concentrations of odorous substances emitted from nitrification chamber No. 1 are equal to the concentrations in chamber No. 2,

- the concentrations in the denitrification chambers are mean concentrations in the phosphorus removal chambers and nitrification chambers;

- the concentration of the compounds was calculated before entering biofilter No. 2 and after exiting the machine, and the results are summarized in Table 4.

Table 4. Concentration values of odorous substances obtained after air purification in biofilter No. 2

\begin{tabular}{|c|c|c|c|c|c|}
\hline $\begin{array}{l}\text { Component } \\
\text { of the air }\end{array}$ & Unit & $\begin{array}{c}\text { Concentration } \\
\text { before } \\
\text { biofilter }\end{array}$ & $\begin{array}{c}\text { Degree of } \\
\text { pollutions } \\
\text { reduction [\%] }\end{array}$ & $\begin{array}{c}\text { Concentration } \\
\text { behind } \\
\text { biofilter }\end{array}$ & Permissible value \\
\hline $\mathrm{SO}_{2}$ & $\mathrm{mg} \cdot \mathrm{m}^{-3}$ & 1.33 & 90.0 & 0.13 & 0.35 \\
\hline $\mathrm{CO}$ & $\mathrm{mg} \cdot \mathrm{m}^{-3}$ & 3.80 & 90.0 & 0.38 & 30.0 \\
\hline $\mathrm{H}_{2} \mathrm{~S}$ & $\mu \mathrm{g} \cdot \mathrm{m}^{-3}$ & 21.89 & 95.0 & 1.09 & 20.0 \\
\hline$\Sigma \mathrm{C}_{\mathrm{x}} \mathrm{H}_{\mathrm{y}}$ & $\mathrm{mg} \cdot \mathrm{m}^{-3}$ & 199.29 & 90.0 & 19.93 & 3.0 \\
\hline$\Sigma$ mercaptans & $\mu \mathrm{g} \cdot \mathrm{m}^{-3}$ & 21.46 & 95.0 & 1.07 & 20.0 \\
\hline Dimethylamine & $\mu \mathrm{g} \cdot \mathrm{m}^{-3}$ & 16.61 & 90.0 & 1.66 & 10.0 \\
\hline Trimethylamine & $\mu \mathrm{g} \cdot \mathrm{m}^{-3}$ & 33.43 & 90.0 & 3.34 & 20.0 \\
\hline Ammonia & $\mu \mathrm{g} \cdot \mathrm{m}^{-3}$ & 44.43 & 90.0 & 4.44 & 400.0 \\
\hline Isobutyric acid & $\mu \mathrm{g} \cdot \mathrm{m}^{-3}$ & 18.50 & 90.0 & 1.85 & - \\
\hline Formaldehyde & $\mu \mathrm{g} \cdot \mathrm{m}^{-3}$ & 134.79 & 90.0 & 13.48 & 50.0 \\
\hline Skatole & $\mathrm{mg} \cdot \mathrm{m}^{-3}$ & $<1.0$ & 90.0 & $<0.1$ & - \\
\hline
\end{tabular}

Source: Author's

The results of the calculations presented in Tables 3 and 4 show that the biofiltration method is a highly effective solution to eliminate of odorous substances from the Wastewater Treatment Plant in Belchatow. The vast majority of contaminants such as $\mathrm{CO}, \mathrm{H}_{2} \mathrm{~S}, \Sigma$ mercaptans, di- and trimethylamine, contained in the exhaust air from the analyzed plant have reached concentrations below the permissible standards for these compounds.

Only in the case of $\mathrm{SO}_{2}$ and $\Sigma \mathrm{C}_{\mathrm{x}} \mathrm{H}_{\mathrm{y}}$ did biofiltration not fully yield the expected results. In the present situation, it is recommended to enrich the filter bed with stimulators that promote the development of selected microorganisms, such as the Drummond strain bacteria, capable of removing undesired compounds from the gases.

Another way is to introduce preparations such as Ferrox or Nutriox into the wastewater collectors. They oxidize odorous substances, which results in transforming these compounds into more stable forms. In this case, however, the effluent should be continuously controlled to prevent the disturbance of the wastewater treatment plant.

\section{Summary and conclusions}

Municipal facilities are particularly troublesome source of emission of malodorous gases. The reason for this is a specific set of odorants emitted (for example, aldehydes, ketones, hydrogen sulphide and mercaptans) as well as the location of facilities in urban or a short distance from the buildings. 
The most important sources of odor emissions from wastewater treatment plants are among other: grit chambers, pumping stations, precipitators, aeration chambers and sludge drying beds. The nuisance of the wastewater treatment plant is therefore the reason for taking appropriate measures, among which the most popular are biological methods, mainly biofiltration.

Based on the performed research and analysis, it was found that biofiltration is the optimum deodorization technology for use in the Wastewater Treatment in Belchatow. The biofiltration method is in fact a modern and innovative solution. It is relatively inexpensive and environmentally friendly. Moreover, it does not generate waste that cannot be managed naturally. The worn filter material is often used as a high-quality compost for horticultural crops. Also, biofiltration does not require large amounts of chemicals whose production is energy intensive, and which would contaminate the environment in the event of a leak. Another positive aspect of biofiltration is the fact that the installations used in this method are constantly being improved, which increases not only the performance of the equipment but also the extent of their use. In addition, it is possible to create an individual biofilter system depending on the needs of the analyzed municipal facilities.

\section{References}

[1] J.S. Devinny, J. Ramesh, A phenomenological review of biofilter models, Chemical Engineering Journal. 2-3 (2005), $188-189$.

[2] Y.-T. Hung, L.K. Wang, N.K. Shammas, Handbook of environment and waste management. Air and Water Pollution Control, World Scientific Publishing, Singapore, 2012.

[3] U. Kita et al., Analysis of trends and solutions in the field of gas deodorization by biofiltration, 277 - 283, http://www.eko-dok.pl/2013/33.pdf [accessed on February 5, 2017] "Analiza trendów i rozwiązań w zakresie dezodoryzacji gazów metodą biofiltracji".

[4] J. Kośmider, B. Mazur - Chrzanowska, B. Wyszyński, Odors, PWN, Warsaw, 2012 "Odory".

[5] T.K. Kumar, Biofiltration of Volatile Organic Compounds (VOCs) - An Overview, Research Journal of Chemical Sciences. 8 (2011), 86.

[6] M. Łebkowska, A. Tabernacka, Biotechnological methods of removing pollutants from waste gases, Biotechnologia. 3 (2000), 148 - 149 "Biotechnologiczne metody usuwania zanieczyszczeń z gazów odlotowych".

[7] Regulation of the Minister of the Environment of 26 January 2010 on reference values for certain substances in the air ( Dz. U. $2010 \mathrm{nr} 16$ poz. 87).

[8] J.D. Rutkowski, Odorous substances and their nuisance, Przeglqd Komunalny. 10 (2005), 67-69 "Substancje odorotwórcze i ich uciążliwość".

[9] I. Sówka et al., The problems of odor nuisance selected of municipal facilities, 409 - 413, http://www.pzits.not.pl/docs/ksiazki/Ekotoks_2008/Sowka\%20409-414.pdf [accessed on February 2, 2017] "Problemy uciążliwości zapachowej wybranych obiektów gospodarki komunalnej".

[10] J. Suschka, Beds and biological filters, Wyd. Politechniki Łódzkiej Filii w Bielsku - Białej, Bielsko - Biała, 2000 "Złoża i filtry biologiczne".

[11] M. Szklarczyk, Biological treatment of waste gases, Wyd. Politechniki Wrocławskiej, Wroclaw, 1991 "Biologiczne oczyszczanie gazów odlotowych".

[12] M. Szklarczyk, Structure, function and advantages of biological filters, Ochrona Powietrza. 1 (1992), $6-8$ "Budowa, działanie i zalety filtrów biologicznych".

[13] M. Szklarczyk, Methods of deodorizing gases in wastewater treatment plants, Przeglqd Komunalny. 11 (2005), 119 - 122 "Metody dezodoryzacji gazów w oczyszczalniach ścieków". 
[14] J. Warych, Treatment of waste gases. Processes and apparatus, WNT, Warsaw, 1998 "Oczyszczanie gazów. Procesy i aparatura".

[15] M. Wierzbińska, Application of the biofiltration method for the deodorization of waste gases using fibrous deposits. Part I. Introduction to biofiltration, Ochrona Powietrza i Problemy Odpadów. 2 (2010), 49 - 51 "Zastosowanie metody biofiltracji do dezodoryzacji gazów odlotowych przy wykorzystaniu złóż włóknistych. Część I. Wprowadzenie do procesu biofiltracji".

[16] M. Wierzbińska, Application of the biofiltration method for the deodorization of waste gases using fibrous deposits. Part III. Studies on the effectiveness of biofiltration of odors using mixture of selected materials of natural origin, Ochrona Powietrza i Problemy Odpadów. 3 (2010), 98 "Zastosowanie metody biofiltracji do dezodoryzacji gazów odlotowych przy wykorzystaniu złóż włóknistych. Część III. Badania efektywności biofiltracji odorów przy zastosowaniu złóż będących mieszaniną wybranych materiałów pochodzenia naturalnego".

[17] M. Wierzbińska, W.E. Modrzelewski, Application of biofilters for deodorization of harmful gases, Ecological Engineering. 41 (2015), 125-132 "Zastosowanie biofiltrów do dezodoryzacji uciążliwych gazów".

[18] http://geoportal.gov.pl/ [accessed on November 28, 2016].

[19] http://www.laminopol.com.pl/pl/72/biofiltry_modulowe [accessed on November 20, 2016]. 